УДК 338.984

\title{
POLISH CONSUMER BEHAVIOUR IN SUPPORT OF SUSTAINABLE DEVELOPMENT
}

\author{
Anna Dąbrowska \\ Institute for Market, Consumption and Business Cycles Research, \\ 87, Jerozolimskie Al., Warszawa, Polska, 02-001, tel. +48 22 628-5585, \\ e-mail: annadabrowskal@wp.pl \\ Mirosława Janoś-Kresło \\ Warsaw School of Economics, \\ 162, Niepodległóści Al., Warszawa, Polska, 02-554, tel. +48 2256460 00, \\ e-mail:mjanos@sgh.waw.pl.
}

The effects of global consumerism highlight the need to intensify efforts aimed at protecting our natural environment, shaping customers' attitudes and increasing consumer awareness in many different countries, in order to promote the idea of sustainable development. The objective of the article is to present the behaviour of Polish consumers and their competence with regard to supporting sustainable development. The authors have undertaken an attempt to identify consumer behaviour strategies connected with purchasing, using and disposing of products. The study is based on the analysis of selected findings of omnibus surveys conducted on a representative sample of 1000 Polish people and on the results of CATI research carried out among 1000 consumers, who were perceived as the most competent ones, representing the group. The studies were conducted in 2013 for the needs of a project funded by the National Science Centre (NCN) (no. 2011/03/B/HS4/04417). The analyses have been supplemented with the data presented by the European Commission and the United Nations. In the article the authors have put forward the thesis about a relatively low level of competence demonstrated by Polish consumers, which is reflected in consumer behaviour, which is not always aligned with the aims of sustainable development.

Key words: consumer behaviour; sustainable development; awareness.

\section{Introduction}

In 2003-2007 thirty countries drafted national documents concerning the implementation of sustainable production and consumption, including six countries in the European Union region: Belgium, Czech Republic, Finland, France, the United Kingdom and Poland. The Polish National Strategy for Changing Production and Consumption Patterns Supporting the Implementation of the Principles of Sustainable Development (Strategia zmian wzorców produkcji i konsumpcji na sprzyjające realizacji zasad trwałego, zrównoważonego rozwoju) adopted in 2003 [21] pointed to the directions of necessary changes contributing to the restructuring of resourcesintensive sectors. The contents of the Strategy also reflected the directions indicated in the Plan of Implementation recommended during the Summit of United Nations on the Sustainable Development, which took place in September 2002 in Johannesburg, and in the earlier UN Declaration on the natural environment and development, adopted

(C) Anna Dąbrowska, Mirosława Janoś-Kresło, 2016 
during the Summit on the Sustainable Development in 1992 in Rio de Janeiro [7]. The Strategy also includes the requirement to undertake «integrated activities affecting production and consumption patterns», in accordance with The OECD Environmental Strategy for the First Decade of the 21st Century (Strategia ochrony środowiska OECD na pierwsze dziesięciolecie XXI wieku) [10].

The European Union aims to support the sustainable development with the application of two flagship initiatives: 1) Resource Efficient Europe, which determines the framework aiming at achieving desirable outcome in terms of effective use of resources in the case of long-term strategies in the areas such as: climate change, research and innovation or environmental protection policy; 2) Industrial Policy for the Globalisation Era, as the dynamic and highly competitive EU manufacturing sector may provide resources and many solutions to social challenges which the EU faces, such as climate change, health and ageing societies, the development of healthy and safe society and thriving social market economy.

It is worth noting that the implementation of these initiatives requires cooperation with the business world, trade unions, academic circles, non-government organizations and consumer associations.

It is also necessary to examine the consumer competences and shape their consumer awareness towards sustainable consumption and exerting influence on the production policy pursued by the business sector.

Sustainable development and sustainable consumption - theoretical approach.

In general, sustainable development is an exploration of the development paths to improve the average standard of living without the increase in, and preferably with the reduction of, environmental pressures [5, p. 82].

In the preamble of the Declaration of Rio de Janeiro on environment and development, its creators listed 23 principles which are essential to provide proper conditions for sustainable development. The Declaration also indicated that:

- Human beings are at the centre of concerns for sustainable development. They have the right to pursue a healthy and productive life in harmony with the natural development;

- Their right to develop must equitably cover the needs and aspirations of the present and future generations;

- All states and all people should cooperate with the common aim of eradicating poverty as an indispensable requirement for sustainable development, in order to decrease the disparities in standards of living and strive to meet the needs of the majority of people in the world;

- The states should cooperate to create global partnership in order to maintain, protect and restore the health and integrity of the Earth's ecosystem;

- In order to achieve sustainable development and enhance the quality of life for all people, the states should reduce or eliminate non-sustainable production and consumption systems, or promote appropriate demographic policy; 
- Environmental issues are best addressed at a certain level, with the participation of all concerned citizens, who should be provided with access to information on natural environment by public authorities;

- Women play a vital role in environmental management and development. Therefore, their full participation is essential to achieve sustainable development;

- Creativity, ideals and courage of young people of the world should be mobilised in order to develop the global partnership, which will help to achieve sustainable development and ensure a better future for us all;

- Indigenous people and their communities and other local communities play a significant role in environmental management and development, owing to their knowledge and traditional practices;

- States and people should cooperate in good faith supporting global partnership fulfilling the principles embodied in the Declaration and in further development of international law in the process of achieving sustainable development.

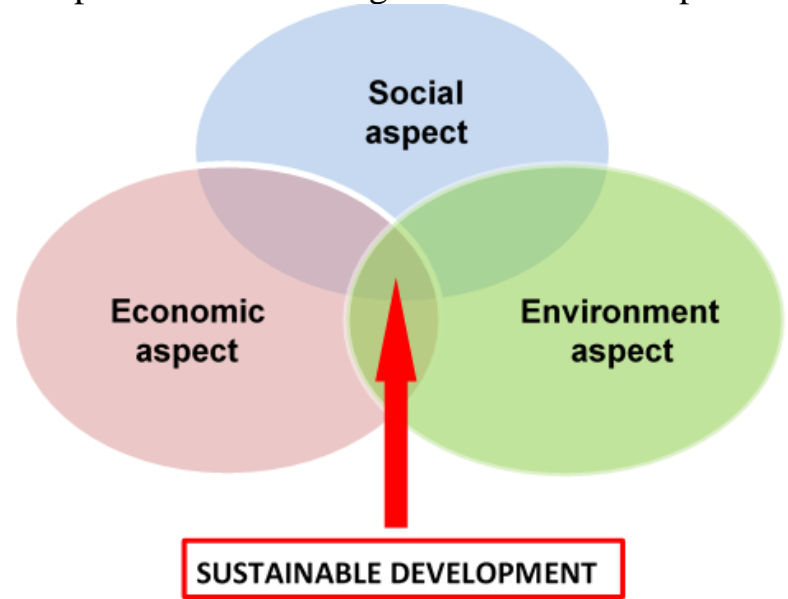

Fig. 1. Components of sustainable development

Source: www.cobro.org.pl

It is frequently emphasised that meeting the challenges of sustainable development is possible thanks to integrating environmental, economic and social policies (Fig. 1), whereby it should be noted that we add three important elements to the concept of environment: access to education, health care system and cultural development, which affect the quality of life, as perceived by us.

In the context of 23 formulated principles, the sustainable development should be seen in a wider perspective, also as a concept of the enhancement of the quality of life, i.e. multi-dimensional fulfilment of existential needs. Sustainable development consists not only in counteracting the degradation of the environment, but also in combatting poverty and destitution, seeking to create the market system which takes into account cooperation, not just competition, as well as counteracting the degradation of the cultural diversity and tradition. The aim of sustainable consumption 
is to enhance the quality of life through pursuing new values and needs in life, new lifestyles as well as different ways of shaping living conditions.

Sustainable consumption is an integral element of sustainable development. One of the most frequently quoted definitions of sustainable consumption is a definition which depicts it as «using goods and services, which satisfy basic needs and affect the improvement of the quality of life, with the simultaneous minimizing of the use of natural resources, toxic materials and emission of waste and pollution throughout the life cycle in such a way which would not limit the possibilities to satisfy the needs of future generations» [20]. Here, we should also quote the definition of sustainable consumption of the Working group on sustainable consumption and production ${ }^{1}$, according to which «sustainable consumption is optimal, conscious and responsible use of available natural resources, goods and services at the level of individuals, households, local communities, business environment, local governments, national governments and international structures in accordance with the principles of sustainable development. It aims at satisfying the needs and improving the quality of life for all people, both locally and globally, while respecting human rights and employees' rights, taking into account the possibilities of meeting the needs of other people, including future generation, preserving and restoring natural capital for them. The attitude of sustainable consumption includes: reducing wastage, production of waste and pollution as well as the proper selection of good and services, which fulfil specific ethical, social and environmental criteria to the greatest extent».

In 2001, Consumption Opportunities. Strategies for change report [4] presented multi-layered approach to sustainable consumption, based on a broad understanding of this concept. The report identifies four levels of the strategies aimed at different agents (Table 1).

The above definitions show that sustainable consumption is the concept which combines various important topics, such as: satisfying needs, improving the quality of life, promoting more effective use of resources as well as the issue of minimizing the amount of waste. An important problem is how to enhance the natural environment through changing the consumption (and production) patters, without necessarily reducing the consumption levels. «Sustainable consumption is not about consuming less, it is about consuming differently, consuming efficiently, and having an improved quality of life. It also means sharing between the richer and the poorer» [6]. Using more effective products, consumers reduce its consumption, but in doing so, they save money, which generate new consumption [3, p. 339].

Table 1

\section{UNEP's approach to sustainable consumption}

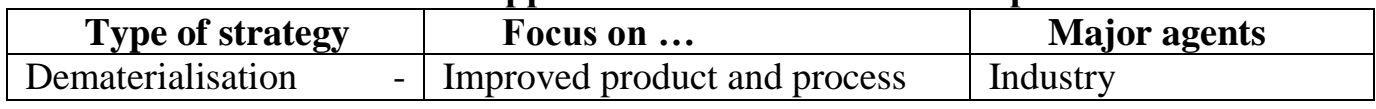

${ }^{1}$ Working group on sustainable consumption and production is one of the teams working for the Team on Corporate Social Responsibility (Zespół ds. Społecznej Odpowiedzialności Przedsiębiorstw) and the initiative of Sustainable Development Vision for the Polish Business (Wizja Zrównoważonego Rozwoju dla Polskiego Biznesu) 2050, www.mg.gov.pl/node/24247. 
Anna Dąbrowska, Mirosława Janoś-Kresło

\begin{tabular}{|c|c|c|}
\hline $\begin{array}{l}\text { Efficient } \\
\text { Consumption }\end{array}$ & $\begin{array}{l}\text { efficiency; higher resource } \\
\text { productivity (What factor of } \\
\text { increased resource productivity } \\
\text { can we achieve in each product } \\
\text { and service, } \\
\text { and across each sector?) }\end{array}$ & $\begin{array}{l}\text { plus } \\
\text { government } \\
\text { consumers }\end{array}$ \\
\hline $\begin{array}{l}\text { Optimisation - Different } \\
\text { Consumption }\end{array}$ & $\begin{array}{l}\text { Changes in infrastructure and } \\
\text { choice Architecture (What } \\
\text { changes in choices and } \\
\text { infrastructure will satisfy } \\
\text { consumer demand } \\
\text { sustainably?) }\end{array}$ & $\begin{array}{l}\text { Government } \\
\text { plus } \\
\text { industry and consumers }\end{array}$ \\
\hline $\begin{array}{l}\text { Optimisation } \\
\text { Conscious } \\
\text { Consumption }\end{array}$ & $\begin{array}{l}\text { More quality of life and less } \\
\text { environmental costs through } \\
\text { 'choosing and using' more } \\
\text { wisely (How can consumers } \\
\text { increase their quality of life by } \\
\text { 'choosing and using' more } \\
\text { wisely?) }\end{array}$ & $\begin{array}{l}\text { Consumers } \\
\text { plus } \\
\text { industry } \\
\text { government }\end{array}$ \\
\hline $\begin{array}{l}\text { Optimisation } \\
\text { Appropriate } \\
\text { Consumption }\end{array}$ & $\begin{array}{l}\text { Type and level of consumption } \\
\text { and } \\
\text { its contribution to quality of life } \\
\text { (Are consumption levels } \\
\text { sustainable? Is consumption the } \\
\text { best way to achieve every type of } \\
\text { quality of life?) }\end{array}$ & $\begin{array}{l}\text { Society at large } \\
\text { plus } \\
\text { communities } \\
\text { citizens }\end{array}$ \\
\hline
\end{tabular}

Source: $[4,20]$

Modern consumer societies are based on the continuous growth of consumer spending, which is essential for the economic functioning of the system. Mass consumption is a dominating feature of highly developed societies. These societies promote consumerism, encouraging or even enforcing the behaviour "which disfavours all its cultural alternatives» [1, p. 79]. Postmodern consumer culture pays special attention to the supremacy of styles and fashion.

Modern consumers live in the time of profound cultural change resulting from the development of new technologies, transformation of social structure and globalization processes. It is the world dominated by mass media which affect the identity, attitudes and consumer behaviour. Postmodernism is particularly evident in consumer choices, which reflect moving away from industrial capitalism regime (expressed with industrial ethos of work and production) towards the idea of indulgence and pleasure, which is characteristic of consumer society [8, p. 161]. A modern man is enchanted with the abundance of goods and services; purchases and consumption constitute the main sense of human existence. Consumption reflects the life of a human being: it becomes a way of establishing an individual's own identity. Buying goods and 
services and their consumption is increasingly pleasant for an individual. The goods are frequently purchased not because of their material value, but due to their symbolic significance, which is an indication of the buyer's status or lifestyle.

Consumer societies are characterised by temporal orientation of «here and now», which actually stands in opposition to sustainable consumption. Making responsible and ethical choices, consumers may affect the behaviour of producers and traders who will adapt their offer to their expectations. It may concern also the goods produced with the respect for the natural environment. In practice, the term «responsible and ethical consumption» is less personal, and it constitutes a challenge for alternative ways of life. Various initiatives of the movement towards ethical/responsible consumption seem to adopt common approach towards political issues such as: Fair Trade and global economic reforms, ecology and animal rights, local and social obligations, as opposed to focusing on individual, private well-being in the discourse on anti-consumerism. The impulse which motivates people to become involved in ethical consumption is altruism and respect towards other human beings, animals or environment [14, p. 49].

According to the World Business Council for Sustainable Development (WBCSD) report concerning a vision of sustainable consumption in 2050, «people live well, within the limits of the planet and society at large. "Living well» is decoupled from the consumption of physical products, and the materials that they contain. The system of production and consumption is aligned with economic, environmental and social sustainability). There is no one single model, but a vast range of options for a better life. Sustainable consumption will be a dominating phenomenon. Nevertheless, consumers will still differ with regard to the level of consciousness concerning the natural environment and social issues, and they will be motivated to change their habits [2].

The British Commission on Sustainable Development creates a concept of «sustainable life», which is "within the capacity of the planet, and simultaneously promoting health, well-being and the quality of life of this generation $/ . . . /$ and future generations». With regard to using goods and services, sustainable life may be achieved by energetic efficiency at home and at work, sustainable travel and sustainable food, reducing the amount of waste, sustainable products and supply chains. Sustainable life should be based on the education, health, well-being and sustainable societies.

Consumers play a crucial role in the realisation of sustainable consumption, both, at present and in the future. Consumer competence is of primary importance for the quality of this role.

\section{Consumer competence.}

According to the Dictionary of Foreign Words, a Latin word competentia refers to specific skills, usefulness, capacity to act and suitability [13, p. 270]. This term also encapsulates knowledge, abilities, potential and attitudes.

In the article we present a definition of consumer competence assumed for the needs of the above said project: the consumer competence represents theoretical knowledge and practical skills, which distinguish a particular individual with regard 
to efficient and effective meeting the low-level and higher-level needs, while maintaining appropriate quality standards and assuming responsibility for his/her choices and decisions [5, p. 54].

Recognizing the importance of consumer competence and the fact that it is one of the most important indicators of the level of the civilisation progress of the society, the authors have undertaken quantitative omnibus research and the studies conducted with the application of CAWI method. The study took into account the concept allowing to examine a consumer competence, among others, in the context of behaviour which is fully consonant with the idea of sustainable consumption.

Sustainable consumption is connected with the decisions made with the respect for the environment, for example: buying eco-friendly products, sorting waste, disposing of batteries using special containers designated for this purpose, recycling goods as well as making more rational purchasing decisions, e.g. buying as many items as I need at a given moment, I donate the used things and things which I find unnecessary to others.

It is worthwhile to take a closer look at consumer profile of customers whose behaviour corresponds to the above said descriptions.

The approach - if we deal with an eco-friendly product and it carries a label indicating this quality, I am willing to buy it even if its price is $10 \%$ higher than of the item which does not have such an indication - is expressed by $64 \%$ of Polish people. It is most frequently represented by men, people aged 35-44, having a tertiary level education, with a professional status of an entrepreneur/a member of managerial staff, who are satisfied with their financial situation, residents of cities below 500,000 inhabitants, from central voivodship.

$63 \%$ of Poles declared regular waste sorting. Such an approach is usually represented by women, individuals aged 45-54, with tertiary level education, indicating a professional status of entrepreneur/member of managerial staff, who perceive their financial situation as average, inhabitants of rural areas, from Wielkopolskie voivodship.

More than half of the respondents $(57 \%)$ admitted that they dispose of the batteries using a special container designated for this purpose. This kind of approach is more frequently represented by women, people aged 56-64, declaring having tertiary level education, with a professional status of an entrepreneur/member of managerial staff, who are satisfied with their financial standing, living in rural areas in Dolnośląskie voivodship (Lower Silesia).

$33 \%$ of Polish people check whether a particular product is biodegradable (recycling) before purchasing it. It is important for both women and men (with a predominance of women), people declaring higher education, with a professional status of a white-collar worker, who see their financial situation as positive, living in the cities above 500,000 inhabitants, from Wielkopolskie voivodship; it should be noted that this particular indication appears to be the least important for elderly people $(65+), 70 \%$ of Polish people donate unnecessary or used items to others. This kind of rational behaviour is typical for women, people aged $45-54$, declaring having tertiary level education, with a professional status of an entrepreneur/member of managerial 
staff, perceiving their financial situation as average, living in rural areas or the cities of 100,000-500,000 residents in Małopolskie voivodship.

Thoughtful purchases are an indication of rational behaviour - we only buy the items which we need at a particular moment. This kind of behaviour was pointed out by $83 \%$ of Polish people. These were mainly women, people aged $45-54$, declaring having secondary level education, with a vocational status of a farmer, perceiving their financial situation as negative, living in the rural areas of Lower Silesian voivodship.

Despite the relatively positive approach declared by a considerable proportion of Polish people, we should also emphasise that, simultaneously, $76 \%$ of the representative sample believe that at present Polish people focus more on consumption (consumerism) than on eco-friendly lifestyle. Such an opinion was most frequently expressed by people aged $45-54$.

Still, it is encouraging to think that over half of Poles (54\%) believe that parents in Poland set a good example for younger people on how to live in harmony with natural environment. At the same time, it is worth noting that important lessons are to be learnt also from children and youth, on condition that such habits and customs will be taught at various stages of education. The distribution of answers is convergent in all surveyed age groups.

The authors of the article examined the issue of competence and rational behaviour in the quantitative study with the application of CATI methodology, covering the sample of 1000 Polish people, seen as more competent individuals representing the population.

The concept of sustainable consumption mainly represented: thoughtful shopping ( $25 \%$ of the sample), buying products which are necessary (24\% of the interviewees), reasonable consumption (buying goods in moderation), according to financial means we have at our disposal (21\% of respondents); the respondents also listed such ideas as e.g. buying in order to consume, not throw away, buying healthy food, responsibility, avoiding overeating.

Every third respondent (34\%) could not define this term. We may assume that they have not come across this term, and, as a consequence, also the problematics associated with the concept. The distribution of responses according to age groups was rather similar; nevertheless, the largest number of responses «I don't know» was indicated by people aged $65+$.

The positive approach towards the concepts of sustainable development and sustainable consumption is reflected in the fact that customers prepare a shopping list before buying grocery products, which may prevent households from throwing away left-over food, both suitable for eating and the one past the expiration date. Such an approach is indicated by $33 \%$ of respondents, and it concerns everyday shopping, or less frequent purchases. $18 \%$ of respondents claim that they never do it, and $21 \%$ of the sample indicate that they sometimes prepare a list of items to buy. It should be noted that $62 \%$ of respondents declare that they always check the stocks of food in the fridge; the interviewees who do it least frequently are aged 65 and more. However, only $39 \%$ pay attention to the size of a packaging; this indication usually concerns people aged $65+$. 
Nevertheless, every second respondent states that there are instances when they throw away food because it is past expiration date, and the minority of the sample $(47 \%)$ claim that they never do it. In turn, $83 \%$ of respondents declare that they do not recall a situation when they would dispose of the food they purchased which would still be good to eat.

According to the Federation of Food Banks (Federacja Banku Żywności), Poland is among the top five countries, where consumers throw away the greatest amount of food (9 million tons), whereby households waste about 2 million tons of food a year.

It is noteworthy that on the 22 May 2015 Lower House of Parliament in France voted in favour of the Environmental Law which prevents supermarkets from disposing of unsold food and orders that the food should be donated to charity organizations (the law applies to shops with the surface of over $400 \mathrm{~m}^{2}$, which need to sign the relevant agreements until June 2016) or utilized in other ways (e.g. as compost or animal feed). The individuals who breach those regulations will be fined in the amount of 75 thousand euro or punished with two years' imprisonment.

«Reducing food waste would help to alleviate the current pressure on limited natural resources, and it would also help to avoid the increase of agricultural production by $60 \%$ in order to satisfy the needs of global population in 2050» - as indicated by the U.N. Food and Agriculture Organisation (FAO) in the report: «Food waste harms climate, water, land and biodiversity». In 20131.3 billion tons of food was wasted around the world [11].

Amongst a group of more competent consumers, $69 \%$ of respondents declared that they pay attention to the fact whether the product they use is eco-friendly (organic origin). It is worth pointing out that in omnibus research $64 \%$ of Polish people presented the following approach - if a product is eco-friendly and carries such a label, I am interested in buying it, even though its price may be $10 \%$ higher than the one which carries no such indication.

Resolute seekers vs. Modern ignorant consumers.

The study allowed the authors to distinguish groups of consumers characterized with similar social and economic features. The group of resolute seekers seems to be the most important segment from the point of view of the considered subject-matter. The group includes people who are most likely to change their buying habits to align them with the idea of «sustainable consumption». They indicate planning only when making larger purchases $(35 \%)$. They examine the products they buy taking many aspects into consideration (origin, ingredients, whether they were produced locally, additives, weight, etc.), they look for information and opinions on the purchased goods. They pay attention to what they buy (quality, price, functionality, certificates). They bring their own, reusable, «eco-friendly» shopping bags to the shop. They acquaint themselves with the terms of contracts or promotions, the procedures concerning claims and returns or replacements of goods. They frequently share their positive opinions with others. They are willing to donate the things they no longer need, such as clothes or books with other people. They are not inclined to buy a new, fashionable item if they have a similar product, which is still useful. This segment includes mainly mature people, between 30 and 59 years, declaring being in a 
relationship, with children, with average income (PLN 2000 - PLN 4000), living in rural areas or cities up to 100,000 residents, more frequently women.

«Modern ignorant consumers» present the attitudes which stand in opposition to the group described above, at least with regard to certain features. It is a segment of people who take advantage of technological innovations, such as paying with pass cards, making Internet purchases and buying novelties, to a greater degree. More than others, they resort to impulse shopping or making purchases influenced by TV commercials. In general, they are less interested in the environmental friendliness or recycling of products, origin of the goods, information placed on the label, but they are interested in the expiry date and whether the product was tested on animals. Prior to making a purchase they are seeking advice and recommendations from others; sometimes they are willing to share their positive views with others. This segment comprises mainly young people (46\% under 29 ), with secondary or tertiary education level (markedly more than in other segments), municipal residents indicating a good financial situation. There are relatively more single people in this segment.

\section{Summary.}

The main idea of the concept of sustainable development is protecting the natural environment and natural resources for future generations. It should be a part of the process focusing on changing the model of consumption, the system of values and the consumer behaviour in order to devise more environmentally-friendly management measures within these areas. Contemporary generations cannot satisfy their needs at the expense of the future generations' possibilities to make free choices with regard to meeting their needs.

In the era of globalisation and its consequences (the development of consumerism) we pay more and more attention to the necessity of changing consumer behaviour towards supporting sustainable development, whose integral element is sustainable consumption.

Consumer behaviour is reflected by competence: namely, consumers' knowledge, attitudes, skills, usefulness, capacity to act and responsibility.

The present research points to diversified consumer behaviour among Polish people. Some consumers understand the concept of sustainable consumption and they try to act responsibly, at least in some areas.

Obviously, education plays a significant role in building consumer awareness. As McGregor [15, p. 542-552] and Mick et al. [16, p. 76] indicate, consumer education aims to help consumers to make better informed decisions (being aware of their consumer rights), which may have a positive impact on them as individuals, on the society and on the environment.

The subject matter has been examined several times by the authors in their numerous publications $[17$, c. 5].

Recognizing the significance of sustainable production and consumption, the European Union recommends close integration of action towards sustainable consumption and production, implementing an action plan for resource-efficient Europe and encouraging member states to pursue the policy through the action plan and the European Semester. At the same time the EU recommends applying a number 
Anna Dąbrowska, Mirosława Janoś-Kresło

of cross-cutting tools which facilitate the implementation and promoting the efforts, such as gradual elimination of non-sustainable products, devising more equitable tax policy, promoting green public procurement, gradual phasing out the subsidies which do not take into account their negative impacts on the environment, supporting research and eco-innovation, internalising environmental costs, creating other marketbased resources and encouraging consumers and the workforce to play an active part in the transition processes. Through improvements in the production process and in the products themselves, consumers may be provided with the goods and services that would empower them to introduce changes, both with regard to their behaviour and their views. The EU draws our attention to the fact that in order to promote sustainable consumption and lifestyles, the role of consumer associations and producers upholding the ideals of fair trade needs to be strengthened so as to promote and protect alternative, non-predatory forms of consumption and support best practice in business.

\section{REFERENCES}

1. Adamczyk G. Moralność i konsumpcja we współczesnym społeczeństwie polskim / G. Adamczyk. - Lublin : Wydawnictwo KUL, 2013.

2. A vision for sustainable consumption. Innovation, collaboration, and the management of choice Council for Sustainable world Electronic resource. - Available from : <www.wbcsd.org. - [Cited: 4.10.2015]

3. Bermejo R. Handbook for a Sustainable Economy / R. Bermejo. - Springer Science+Business, Media Dortrecht, 2014.

4. Consumption Opportunities Strategies for change a report for decision-makers. - Geneva : UNEP, 2001.

5. Dąrowska A. Kompetencje konsumentów. Innowacyjne zachowania, zrównoważona konsumpcja / Dąbrowska A., Bylok F., Janoś-Kresło M., Kiełczewski D., Ozimek I. - Warsaw : PWE, 2015.

6. de Larderel J. A. Director UNEP DTIE / J. A. de Larderel // 4th International Business Forum, October 1999.

7. Deklaracja $\mathrm{z}$ Rio de Janeiro w sprawie środowiska i rozwoju, - Electronic resource - Available from : <http://www.mipe.oswiata.org.pl/rozwoj/doc/deklaracja_z_rio.pdf>, [Cited: 4.10.2015].

8. Dunn R. G. Identifying consumption. Subjects and Objects in Consumer Society / R. G. Dunn. Philadelphia : Temple University Press, 2008.

9. Eco-efficiency. - Paris : OECD, 2001.

10. Environmental Strategy for the First Decade of the 21st Century. - Paris : OECD, 2001.

11. Food waste harms climate, water, land and biodiversity - new FAO report, 11 September 2013, Electronic resource. - Available from : http://www.fao.org/newa/story/en/. - [Cited: 25.10.2015].

12. Francja zakazała supermarketom wyrzucania niesprzedanego jedzenia, Electronic resource. Available from : http://www.polskieradio.pl/42/259/Artykul/1447445,Francja-zakazala-supermarketomwyrzucac-niesprzedana-zywnosc. - [Cited: 4.10.2015].

13. Kopaliński $W$. Słownik wyrazów obcych i zwrotów obcojęzycznych / W. Kopaliński. - Warsaw : Wiedza Powszechna, 1994.

14. Lewis T. Ethical consumption. A critical introduction / T. Lewis, E. Potter. - London and New York : Routledge, 2011.

15. McGregor S. Ideological maps of consumer education / S. McGregor // International Journal of Consumer Studies. - 2008. - № 32.

16. Mick D. Et al Transformative consumer research: For personal and collective well-being / Mick D., Pettigrew S., Pechmann C., \& Ozanne J. - New York : Routledge, 2014. - (cited: E. B. Goldschmith, Social Influence and Sustainable Consumption, Springer International Publishing Switzerland, 2015). 
Anna Dąbrowska, Mirosława Janoś-Kresło

17. Ochrona i edukacja konsumentów na wybranych rynkach usług / A. Dąbrowska (scientific editor). - Warszawa : PWE, 2013.

18. Propagowanie zrównoważonej produkcji i konsumpcji w Unii Europejskiej// Europejski Komitet Ekonomiczno-Społeczny. - Brussels, 26 April 2012, Electronic resource. - Available from : http://www.ine-isd.org.pl/theme/UploadFiles/File/ekes/produkcja_konsumpcja.pdf. - [Cited: 28.09.2015]

19. Przez zrównoważoną konsumpcję do zrównoważonego rozwoju (Through sustainable consumption towards sustainable development). - Ministerstwo Gospodarki, (the Ministry of Economy), Electronic resource. - Available from : <www.mg.gov.pl/Wspieranie.../Zrownowazona + Produkcja $+i+$ Konsumpcja>

20. Scholl G. What is Sustainable Consumption? / G. Scholl. -Germany : Institute for Ecological Economy Research (IÖW), April, 2011.

21. Strategia zmian wzorców produkcji i konsumpcji na sprzyjające realizacji zasad trwałego, zrównoważonego rozwoju (The Polish National Strategy for Changing Production and Consumption Patterns Supporting the Implementation of the Principles of Sustainable Development). //The government document adopted by the Council of Ministers on 14 October 2003. - Warsaw. - Ministry of Economy, Labour and Social Policy.

\title{
ПОВЕДІНКА ПОЛЬСЬКИХ СПОЖИВАЧІВ ДЛЯ ПІДТРИМКИ СТАЛОГО РОЗВИТКУ
}

\author{
Анна Добровська \\ Інститут ринку, споживання і дослідження бізнес-циклів, \\ Алея Срусалимська, 87, м. Варшава, Республіка Польща, 02-001, тел. +48 22 628-5585, \\ e-mail:annadabrowskal@wp.pl \\ Мирослава Янош-Кресло \\ Варшавська школа економіки, \\ Алея Незалежності, 162, м. Варшава, Республіка Польща, 02-55, тел. +48 2256460 00, \\ e-mail:mjanos@sgh.waw.pl.
}

Наслідки глобального споживання наголошують на необхідності активізації зусиль, спрямованих на охорону нашого навколишнього природного середовища, вплив на ставлення клієнтів і підвищення обізнаності споживачів у багатьох країнах з метою просування ідеї сталого розвитку. Мета статті полягає в дослідженні поведінки споживачів Польщі та їхньої компетенції щодо підтримки сталого розвитку. Автори зробили спробу визначити стратегії споживчої поведінки, пов'язані з придбанням, використанням та утилізацією продукції. Робота заснована на аналізі відібраних результатів багатоцільових досліджень, проведених за репрезентативною вибіркою 1000 поляків і за результатами дослідження САТІ, проведених серед 1000 споживачів, визначених як найкомпетентніші з групи. Дослідження проведені 2013 року для потреб проекту, що фінансується Національним науковим центром (№ 2011/03 / В / ГС4 / 04417). Аналіз доповнений даними, представленими Європейською комісією та Організацією Об'єднаних Націй. У статті автори висунули тезу про відносно низький рівень компетентності, продемонстрований польськими споживачами, що знайшло відображення в споживчій поведінці, яка не завжди збігається з цілями сталого розвитку.

Ключові слова: поведінка споживачів; сталий розвиток; обізнаність. 